\title{
3 Guiding Eros Toward Wisdom in Alcibiades I
}

Vanessa Jansche

The Socratic method is generally associated with a special type of questioning that aims at testing the consistency of an argument and usually forces the participant to reconsider his or her initial beliefs. But if one looks closely at the academic literature and the classroom practice, there seems to be no shared definition of the Socratic method that is broadly accepted. On the contrary, there are various views of what it actually consists of. ${ }^{1}$

In this chapter, I argue that the Socratic method consists of redirecting an erotic - and therefore potentially tyrannical - soul toward philosophy. The outline of my argument is as follows: based on passages in the Symposium, Socrates describes himself as an expert in matters of love with eros understood as a fundamental drive that deeply shapes human life. I complement this picture of eros by turning to the Republic, where Socrates explains how the philosopher's eros aims at wisdom and is stronger than any other desire within the philosopher's soul. Astonishingly, Socrates emphasizes that the tyrant, too, is driven by an enormously strong eros, which forces the affected person to live a tyrannical life strictly opposed to a philosophical one.

In a next step, I seek to elucidate in Alcibiades I how Socrates tries to turn his lover's eros toward philosophy. In this dialog, Socrates meets Alcibiades, an ambitious aristocrat, whose eros aims at political power to "rule the world." By working out the contradictions in Alcibiades' understandings of politics and justice, Socrates forces him to admit he does not have the necessary knowledge to become a good politician. The refutation of Alcibiades' mistaken ideas enables Socrates to redirect the young man's eros. Socrates further points out the importance of selfknowledge, an explicit reference to his own philosophical motivation derived from the Delphic maxim to "know thyself." Finally, I conclude with some remarks on how the Socratic method as presented in the Alcibiades I might be applicable to classroom practice in the twenty-first century.

\section{Different Accounts of the Socratic Method}

Scholars distinguish two forms of the Socratic method present in Plato's dialogs. The first type consists in refuting the interlocutor's opinion by pointing out its inconsistencies. This confutative method is most prominent in the early dialogs like Charmides, Laches, or Republic I. ${ }^{2}$ Because all these dialogs end in aporia, some scholars conclude that Socrates was a skeptic and that the rejection of any definition given by his partners demonstrates the limits of human reason. ${ }^{3}$ The second type of Socratic method is a way of imparting knowledge by asking specific questions. Commentators who favor this maieutic approach refer to Meno or Theaetetus. ${ }^{4}$ They claim that Socrates' main intention is to help people "give birth" to their own ideas. Both approaches are consistent in themselves, but once we look for a way to combine them into one overall method, we stumble upon the so-called Socratic ignorance.

Socrates, as presented by Plato, claims that he does not know the things he is asking his interlocutors. ${ }^{5}$ If Socrates' ignorance is seen simply as an ironic stylistic device, the Socratic method consequently appears as a way to impart knowledge or - in a negative way - to manipulate. ${ }^{6}$ 
36 Vanessa Jansche

However, this account contrasts with diverse passages within the Platonic corpus where Socrates insists on not knowing what matters most in life. He explains his epistemic position most prointly in the Apolocher and he firmly rejects hoth aspects - the emphasis on his ignorance and the idea that he ever had a pupil (Apology, 33 b). Bohtrect the thesis that Socrates' ignorance is the rejection of the idea of teaching - seem to contradict the thesis that Socrat simply ironic.

An alternative would be to take the Socratic ignorance literally. If Socrates really does not know Anat courage, justice, prudence, or piety mean, then his way of questioning his fellow citizens is what or discussion that does not presuppose any specific method wh knowledge. The Socratc such that it enables the interloct not interfere with the content. Even though this interpretation seems prosing fails to explain one crucial element of the Socratic dialog. Socrats is never satisfied with simply assisting his interlocutor to generate a claim. He always insists on testing the idea advanced by his partner (Apology, 29e; Theaetetus, 150c). If we take his ignorance literally, how can Socrates partner (Apolly test actly?

Ag the Socratic method that does not focus on Against this background, Iorfer and Socratic ignorance but rather on Soctic know in a broader sense: I define it by its overall philosophical motivation ther rhetorical techniques. I consequently shift my focus on Socrates' intention while his interlocutor, i.e., Alcibiades, in the dialog of the same name.

\section{Socratic Expertise on Ero}

As stated in the beginning, Socrates is famous for his ignorance. He frankly admits that he does not As know the things he is asking his interlocitors (Apolog, 23a). In this light the rall por further invesSocrates does claim to know something become even more interesting and call for further investigation. Maybe one of the most revealing dialogs about Socrates himself is the Symposium. As I later take a closer look at the relationship between Alcibiades and Socrates in the Alcibiades I, it is Ilater take a closer look at the gives the most impressive characterization of his master through the worth mouth of Alcibiades. $A$

course, for Plato. ${ }^{8}$. In Symposium, Agathon celebrates his victory at an Athenian festival in honor of Dionysius and
invites his guests to a banquet (Symposium, 173a). ${ }^{9}$ Instead of raising their glasses to toast their hos Agathon, the guests instead agree on delivering speeches to praise $\operatorname{Eros}^{10}(177 \mathrm{~d})$. So, what doe Socrates know about it?

Eros, i.e love is always love of something (199e). Love is a relation between the lover and th Erose expresses a desire for something, but we only desir beloved - it is not he belos i: things we do not have yet or we already has attracted by beauty, it follows that he cannot be beautiful himself (201c). The pir Socrates holds, misunderstood this fundamental structure. He ascribed to Eros are really the attributes of the beloved.

But if Eros is not beautiful, this does not mean necessarly that he is ugly, as Socrates explain reproducing a conversation he once had with the priestess Diotima (202b). He is in between, th metaxy; and Eros is neither ignorant nor wise - but philosophical (204b). This point is remarkable a metaxy, and Eros is of it might give us an enriched idea of whe phe wisdom is relationa - it has a center of reference, naty we reached what it is seeking. The philosopher is neither ignorant (he knows that he does not know) no wise (he knows that he does not know) - a clear reference to socrates hinself. Thus, philosoph represents the basic erotic condition of human life: we yearn for the things that we do not have y
Guiding Eros Toward Wisdom in Alcibiades I 37 but so desperately need. This link between eros and philosophy later becomes more evident when Alcibiades identifies Socrates as Eros (214b)

Love is not completion but the striving for it. It longs for the beautiful by which it hopes to attain the good and everyone wants to have the good forever (205a). Diotima describes how a true erotic lover can reach the highest good and hence satisfy his desire. First, as a young man, he loves a beautiful person and impregnates him with beautiful speeches (210a). After a while he realizes that there are many beautiful people and his beloved is not the only one. At this point, the lover extend his love to all beautiful people. If there are many beautiful bodies, beauty cannot be identical to any specific one (210b). It is pivotal to note that the expansion on the physical level - many beautiful bodies - is the first step to overcome the mind's fixation on an empirical object. He thus has to overcome the sensual level and enter the intellectual sphere. ${ }^{11}$ Therefore, he now loves his lover's beautiful soul which is of greater consistency than his body.

At this stage, the philosopher lover aims at improving the beloved soul through "beautiful speeches." He continues to recognize the beauty in the community's laws and morals $(210 \mathrm{c})$, until
he becomes aware of the beauty of science and knowledge $(210 \mathrm{c} / \mathrm{d})$. At this abstract level, he is only one step away from the end. By practicing sciences and training his intellect, the lover will be able to grasp the beauty itself which is absolute and perfect. Although the ascent to the beautiful becomes more and more abstract, it is worth going: once the philosopher perceives beauty itself, he knows the source of all beautiful things which are always imperfect in some way and therefore never beautiful as their cause. Knowing beauty itself enables the lover to create true virtue (212a) and only then is he at the end of his journey: he gains the good by creating it.

If one stops reading at this point, all the prerequisites regarding Plato's concept of love seem to be met: it is impersonal, ignoring the individual, objective, and only interested in intellectual objects, i.e., the Forms. ${ }^{12}$ But this is not actually the case. To prove Socrates' and hence philosophy's personal erotic engagement, Plato appeals to someone as a witness whose credibility regarding love no one in Athens would have dared to question: Alcibiades ${ }^{13}$ who has the last saying in the Symposium and his description of Socrates is anything but prudish. ${ }^{14}$

Alcibiades enters Agathon's house accompanied by dancers and flutists. He is drunk and wants to share his inebriation with the other guests. Alcibiades refuses to praise Eros but instead wants to pay tribute to Socrates (214d). This scene introducing Alcibiades already gives an idea of the young Athenian's major characteristics: on the one hand, he is dictatorial and gives orders, and on the othe hand, he is desperately in love with Socrates that he even associates his beloved with Eros itself

How does he describe Socrates? Alcibiades compares him to the satyr Marsyas, a sort of demon, charms his fellows with his dialogs. Alcibiades confesses that he is so deeply moved by Socrates' words that he considers his own life not worth living on those terms (216a). And although it seems that Socrates mostly speaks about craftsmen, his words are full of wisdom and reason and "none are so divine, so rich in images of virtue" (222a).

Like Eros, Socrates always pursues the beautiful and is purely philosophical (216d). Driven by his love for wisdom, Socrates has achieved the highest level of Diotima's ascent by realizing virtue abundance $(220 \mathrm{a} / \mathrm{b}, 221 \mathrm{~b})$. This is the reason why Alcibiades loves Socrates: he literally embodies the good. By following his eros, Socrates became what he was searching for.

Seemingly, Alcibiades is able to acknowledge the beauty of Socrates but is unable to follow him and lead a philosophical life. Alcibiades' eros was corrupted by his desire for power. Alcibiades represents another erotic character that is not philosophical but tyrannical. This will become more evident in the next section consulting the Republic and Plato's portrayal of the philosopher and the tyrant.

For present purposes, this short sketch of the Symposium shall be sufficient to show Socrates' expertise on love. Philosophy, as Socrates practices it, is erotic. One could even say that Socratic 
philosophy is the most profound expression of love. For this reason, Socrates knows that an erotic nature is highly deficient and yearns for its beloved object.

\section{Eros as Common Ground of Philosophy and Tyranny}

So far, we have met an erotic person going in one direction - the ascent to beauty and the good. Although Socrates' previous speakers have no philosophical ambitions, one cannot deny their Although Socrates' previous spal speech is that of Alcibiades - he represents erotic passion that enthusiasm. The nus icians, crownec resembles mado with ivy and considerably drunk (Symposium, 212e) ilosophical sense. He is in love with Socrates and ecstasy. Alcibiades is erotic, but surely not in a philosophical se. Heich but chooses another way of life. In the Republic, Plato describes

to the philosopher regarding his erotic passion - the tyrant. It is therefore worth carving out the parallels of the philosopher in the Symposium and the Republic After Socrates has stated that the philosopher met potential objections $(474 \mathrm{~b}) .{ }^{15}$ First, he remarks tha defines what a real philosopher is in order to meet potent ust parts of it. Philosophers love all sorts o loving something means wanting it completely and not just parto on the only ones wh knowledge because they desire all wisdom (475b). Because phlis are curious, he specifies his definition: whereas lovers of spectacles are delighted by beautiful sound and sights, the philosopher looks for the beauty itself. Here again, the philosopher is characterized a someone who goes beyond the phenomena and looks for the intellectual principle that manifests itse someone who goes in material objects. The other lovers - thosed by the sheer amount and variety of sensual effects, $b$ of Diotima's ascent: They are overwhelmed by the sheer amount and variful things without realizing who they are not capable of

they love about them. A philosopher is committed to eros and yearns for the good, but her or his passion is not necessaril
satisfied. There are multiple dangers to a philosophical nature: First, the philosophical soul's so-calle positive attributes - bravery, sobriety, and more - can pull it away from philosophy. ${ }^{16} \mathrm{~A}$ secon danger is miseducation: Socrates states that bad education harms endowed souls more than othe (491e) The philosophical soul features cognitive skills that can be exploited for any purpose - be it (491e). The philosophical soul ceatur co con nature will never be the cause of anything great, either f good or in bad faith. After all, "[ $\ldots$.. ] weak nature will never be the cause of anything great, either good or evil" (491e). Philosophical natures can theref
choose to use their excellence in a wrong sense.

Once the soul is corrupted, it becomes very difficult to recapture it for philosophy. Because $h$ fellow men are also aware of his talents, they try to exploit the young person by cajoling him. In th regard, it is very unlikely that the young arrogant man will listen to someone who tells him the tru regard, it is very unlikely that the young ars he starts to philosophize (494d). Later we will see ho he is in a deplorably ignorant state unless he starts to philosophize (49 fim for philosophy, a task th Socrates tries to convince
Socrates ultimately fails.

Socrates ultimately fails. To understand the consequences of a corrupted soul, a look at the decay of political constitutio
in the Republic reveals that tyranny grows on the grounds of democracy. ${ }^{17}$ Because every inst ficient form of government fails by absolutizing its guiding principle, democracy's biggest proble is its love for liberty (562c). Democracy tends to arbitrariness and even anarchy, because democr is its love for liberty (562c). Democh disapprove of any sort of rule and hierarchy (563a). Wher love their freedom so much that they disapprove of any sort of rule and oligarch's aim, i.e., wealth, the oligarchic person is still able to control his ambitions to achieve an oligarch's aim, i.e., wealh, democrat fails to overrule his desires, because his soul has never learned to obey. Moreov the democrat's

common rules.

This toxic mixture of unbounded desires and weakness makes the democrat's soul very prone to seduction of those whom Plato calls "dread magi and king-makers" (572e). ${ }^{19}$ These people introdı the young democrat to a debauched lifestyle full of conviviality. He is overwhelmed by all sorts of pleasures; and the more he follows his lust, the more he destroys prudence in his soul. Finally, he is willing to devote himself completely to his desires, even the forbidden and most wicked ones, ${ }^{20}$ and "all [his] doings [...] are entirely swayed by the indwelling tyrant Eros" (573d).

The development from a democratic to a tyrannical person is illuminating: by indulging his numerous passions, he loses control to one desire that eventually dominates all others. Plato calls this ruling passion eros; and the tyrant himself is subjected to the tyrant Eros. Some translations try to avoid the word "eros" in this context, although the Greek text leaves no doubt that eros also stands for ruthless appetite. ${ }^{21}$ And it is indeed astonishing that the same force that earlier was described as the decisive drive toward wisdom and beauty might also deprave a man or even a whole state; or, as Scott puts it: "eros is to the soul of the tyrant as a tyrant is to his city,"22

Apparently, the philosophical and the tyrannical eros are not similar with regard to contents, but they do share some formal characteristics: Once eros is unleashed, it is impossible for the obsessed to resist: the philosopher is unable to do anything else than search for truth, whereas the tyrant must indulge his unnecessary desires no matter what the cost. From an outside perspective, this radicalism may manifest itself in asocial behavior. Whereas the philosopher in his admiration for truth is unwilling to engage in the conventional struggle for power, honor, and money, the tyrant ignores social rules and anything else that might limit his pleonexia. ${ }^{23}$ Philosopher and tyrant are driven by the same force to the extreme, but in opposite directions. Both share the same talent for enthus but, unfortunately, the tyrant choses the wrong object of love and is condemned to live an unjust an therefore unhappy life (576c). ${ }^{24}$

It is worth repeating that only a gifted person with certain capacities can achieve greatness, which also means that only an exceptional character can become a veritable tyrant. As Socrates had mentioned earlier in the Republic, the young talent must not be corrupted by the moral standards of the many but his love must be directed toward truth. We have seen that a democratic environment is especially dangerous because its laissez-faire attitude promotes desires to grow unchecked.

\section{The Socratic Method as a Deflection of Eros: The Case of Alcibiades I}

In Alcibiades $I,{ }^{25}$ Socrates meets the twenty-year-old Alcibiades who plans to stake out a leading position in Athens. His political ambitions are the starting point of the following conversation. In Socrates' attempt to turn Alcibiades' eros toward wisdom, I argue there are three steps. First, he seduces the young man and catches his attention. Second, Socrates dismantles Alcibiades' ignorance by refuting the aristocrat's incomplete beliefs about politics and justice. Once Alcibiades accepts his deficient state, Socrates can finally redirect the young man's eros toward wisdom by teaching him the art of self-knowledge.

\section{Socratic Seduction}

Plato's introduction of the two characters is revealing. The initial encounter of Socrates and Alcibiades resembles the idea of paiderastia: the ancient Athenian institution of an elder citizen taking a teenager as his lover, who is supposed to learn virtue in return. The date of their first meeting is not accidental: Socrates' daimonion has forbidden him to approach Alcibiades earlier although he has stalked him for years. The reason for Socrates' patience must be linked to his educational intention: now that Alcibiades' physical attractiveness is beginning to vanish, ${ }^{26}$ his intellectual beauty is on the rise. This is a first sign that Socrates is not interested in Alcibiades' body but rather in his soul, as he later confirms (131d). At twenty, Alcibiades stands at the threshold to itical institution in democratic Athens at that time. If Socrates wants to influence Alcibiades'
development, he cannot wait any longer: Alcibiades is now old enough to enter the political stage. 
Therefore, he is potentially endangered by the corruptive effects of power and democratic publi opinion, both of which can harm a talented soul (Republic, 494c). ${ }^{27}$

Socrates' further decription of Alcibiades shows that the young man is already at the brink o tyranny: Alcibiades thinks that he has "no need of any man in any matter" (104a), because he i already perfect. He is very beautiful and athletic, he comes from the noblest families of Athens, $h$ has powerful friends - his guardian is Pericles himself - and he is very rich which, however, seem the least important to him $(104 \mathrm{~b}-\mathrm{c})$. Socrates has observed that Alcibiades is aware of his excep tional personality, seeing that his arrogant attitude has driven away all his lovers (103b). ${ }^{28}$

But why does Socrates not give up on him? The following passage is a very impressiv characterization of the young Athenian and delivers insight into Socrates' love: Socrates admit that he would have ren the young man enjoying his life. But $h$ claims thatcibil one may say, the whole world with [his] name and [his] power" $(105 \mathrm{c})$. The desire for absolut domination clearly implies a strong eros. Socrates hopes to persuade Alcibiades that onl Socrates can give what Alcibiades desires (105e) - Socrates claims to be the only one who ca fulfill Alcibiades' love.

Socrates' statement in this passage is quite uncommon because he usually never makes promise Socits sto consideration, his word make sense in two ways: he seems to acknowledge Alcibiades' strong eros which makes hir make sense in two ways. he seems to acknowedge Alcibiads' stong receptive to both philosophy and tyranny. ${ }^{30}$ Thanks to Socrates' explanation, ${ }^{31}$ Alcibiades learn about his own secret hopes and ambitions, probably for the first time in his life, because he neithe refuses nor does he confirm Socrates' claim (105c). ${ }^{32}$

Moreover, by promising Alcibiades what he desires, Socrates easily catches the young man attention, who actually listens full of curiosity (106c). As Zuckert remarks, “ "... Socrates used h knowledge of ta erotika to 'seduce' Alcibiades. ${ }^{\prime 33}$ Of course, the power Socrates promises is $n$ quite what Alcibiades expects: before ruling others, Alcibiades has to control himself first, a tas quite what Alcibiades expects:
which he does not find easy.
(4

\section{Socratic Refutation}

Once Socrates secures Alcibiades' attention by having appealed to his eros, he explains ho Alcibion making a long speech, b (106b). Socrates is able to give a lor speech, as he later demonstrates $(120 \mathrm{e}-124 \mathrm{~b})$, so the reason for the dialogical approach cannot Socrates' poor oratorical skills. It is rather a first hint that the dialog as a form is central to Socrate philosophy and his method. ${ }^{35}$ Only by conducting a Socratic dialog can Alcibiades attain pow over himself and others. It is worth noting to see how the dialog influences Alcibiades' thinking ar what overall function it plays in turning Alcibiades' eros toward philosophy. Thus, I focus on th dialog's effects and not on its subject, i.e., justice.

The starting point is Alcibiades' political ambition. By entering the assembly and participating The starting point is Alcibiades' political ambition. By entering the assembly and participating public deliberations, Alcibiades asserts that he is able to consult the Athenians in political affai (106c). Giving advice to someone implies a difference in knowledge between the advisor and th advised; hence, Alcibiades' intention means that he claims to know more than his fellow citize (106d). Socrates, however, deconstructs the young man's presumption by showing that he does $n$ know anything at all about politics which, he says, is based on justice (109c).

Although Socrates dismantles Alcibiades' ignorance of justice (112b), the latter is not ve Althou Soctes ditical leadersh Instead, Alcibiades changes the topic by stating "that the Athenians and the rest of the Greeks rare deliberate as to which is the more just or unjust course $[\ldots]$ and consider which course will pro more expedient in the result" (113d). This tactical move from the just to the expedient reve
Alcibiades' inconsistency and flippancy. He thinks that by arbitrarily changing the subject, he will be able to escape Socratic refutation. But he ignores that his maneuver enlarges his claim of knowledge which has already been proven baseless. He even anticipates Socrates' argument and refuses to be proven wrong in the same way as before (113e)

After Socrates has revealed that Alcibiades neither knows what justice is nor what is expedient, Alcibiades tries one final elusion. Because Alcibiades thinks that his fellow citizens do not know anything about the just and expedient, he sees no need for himself to learn about these either: "For I am sure that my natural powers alone will give me an easy victory over them" $(119 \mathrm{c})$. Facing this level of hubris and convenience, Socrates highlights during a long speech that Alcibiades' true rivals are not his untalented fellows, but the kings of Persia and Sparta. These monarchs excel Alcibiades' gifts by far so that his only chance to compete aginst them is by "pain and skill." Therefore, Socrates recommends that Alcibiades listen to him and he Delphic molt " $k$ now thyself" $(124 \mathrm{a} / \mathrm{b})$

Some interpreters criticize that Socrates would never admire wealth and power and therefore argue that this hymn on the Persian and Spartan kings proves the dialog's inauthenticity. ${ }^{36} \mathrm{But}$ if one takes Socrates' educational intention into account, this speech seems to have a persuasive function and rather expresses Alcibiades' thoughts than those of Socrates. ${ }^{37}$ By pointing at his true comthe educators attempt to persude a talented soul of tis ignorance (Republic, 494d). All of Socrates' efforts aim at bringing Alcibiades to terms. The young man must be made to accept his ignorance and the consequences of it; otherwise, he is lost for philosophy and will probably continue his way toward tyranny.

\section{Socratic Teaching}

The last section of the dialog keeps its dialectical structure, even though Socrates is trying to pass knowledge on to Alcibiades. After the speech about his Persian and Spartan rivals, Alcibiades appears understanding and asks that Socrates enlighten him. Before Socrates starts his lesson, he emphasizes the importance of joint consideration (124d). Both partners commit to the inquiry Socrates as well as Alcibiades. This call for cooperation anticipates the process of mutual selfknowledge described in the allegory of the reflecting eye at the end (133d).

Socrates starts once again by asking Alcibiades how to become an Athenian gentleman whose task it is to improve the city (124e). A city is well managed when its citizens are friends. But Alcibiades cannot tell how to create friendship and once again he is helpless. In contrast to his former failures he now blames himself, admitting that "I do not even know what I mean myself, and I fear that for some time past I have lived unaware in a disgraceful condition" (127d). Here, Socrates has seemingly succeeded in qualifying Alcibiades for a certain level of self-reflection. He therefore encourages Alcibiades instead of rebuking him. Alcibiades again asks what to do and Socrates again replies that the young man has to answer his questions (127e)

Now that Alcibiades does not object anymore, Socrates directs the conversation toward the question of the self. Because Alcibiades understands that he has to care for himself, Socrates reasons that self-care presupposes self-knowledge. Therefore, he concludes, they have to understand what the self actually is, for otherwise they could not improve it (129a) ${ }^{38}$ What, then, is the self? Socrates identifies the self with the soul (130d). This implies that Socrates is Alcibiades' true lover because he loves his soul and not his physical appearance (131a). The soul knows itself by reflecting itself in another soul.

How does this work? An eye, for example, sees itself when looking into a mirror. Now, an eye is a mirror itself if another eye looks into it and reflects itself in the other eye's pupil (133a). Therefore, Socrates concludes that a soul can know itself by looking into another soul, or more precisely into 
its best part; that is where we find wisdom (133b). ${ }^{39}$ Only those who know themselves by this wa will make the right decisions for themselves and their community and will be good politician The allegory imper The alleg lo mutually reflecting one anoher. Becalse the self is the son a that houses reason, he self knows itself when it becomes aware of its intellect. This onl through dialog. By giving account to a counterpart, own thinking. ${ }^{40}$ In Alcibiades' case, he gets to know himself through Socrates who reflects th young man's beliefs and tests them. ${ }^{41}$

Socrates explains that the soul only knows itself if it looks into another soul, "and especially ; that ris of it which occurs the virtue of a soul - wisdom" (133b). Thus, self-knowledge mear hat rensen sel to a correlate. By illustrating how knowledge and the knowledge of being, beauty, and good seen to conrelate. By ills know oneself, Socrates initiates Alcibiades into the heart of philosophicalinquily. The desire of th sort of knowledge implies that it is not present yet. Yearning for something that one lacks but wh one desperately needs is an unambiguous description of eros; hence, once one has accepted his her ignorance concerning the self and the good, eros becomes the driving force to search $f$ her ig methodological link between self-knowledge ar philosophical inquiry.

philosophical inquir. In Alcibiades I Socrates' method has two main components. First, he inspires Alcibiades' eros proving his ignorance. Once Alcibiades is ready to accept his deficiency, Socrates can move on introducing him to philosophy. This also happens through dialectical inquiry, even though the la section of Alcibiades I is more of a monologue. This, however, does not have to be a contradictio just as Socrates makes a long speech to cut back Alcibiades' pride, he uses the allegory to encoura; and stimulate Alcibiades' mind.

At the end of the dialog, Socrates and Alcibiades have changed their parts. Alcibiades declar At the end of the dialog, Socrates and Alcibiades have chan about justice (135d/e). However, $t$. now beloved Socrates is skeptical about Alcibiades' love. He concludes that the seductive power the Athenian people might overcome both, which proves later to be true.

\section{Conclusion: Applying Guiding Eros Toward Wisdom}

So far I have argued that eros represents the decisive power which turns a person to philosophy suce him or her to tyranny. The philosopher Socrates who is, due to his profession, an expert seduces him or her to tyranny. The philosopher Socrates wisdom. After gaining the young mat love matters, tries to redirect Alcibiades' eros toward wisdom. After gaining the young ma attention, Socrates reveals that Alcibiades lacks knowledge of politics, justice, and himself. overcome his deficiency, Alcibiades has to reflect his most wise and prudent part of himself another soul. This theory of self-knowledge refers to the dialog itself. ${ }^{42}$ What then are the imf cations for the Socratic method and how can we apply it?

My in My interpretation of Alcibiades I may ofrical and didactic approaches, it seems impossible Because Socrates limit the Socratic method to one technique. Still, if one hastily denies the unity of the Socra method, one ignores the coherence it produces throughout the dialog. Therefore, I conclude that Socratic method is the attempt to turn the interlocutor's eros toward wisdom. To accomplish $t$ feat, Socrates uses dialectical refutations, exhorting monologues, or encouraging allegorie: anything that may help to make the partner accept his ignorance and motivate him to overcome anything the Socratic philosop current status. Of course, it is poir ent the is no need to call them "Socratic" anymo

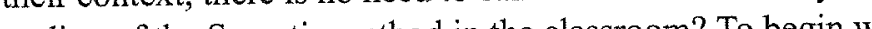
How can we apply this understanding of the Socratic method in the classroom? To begin $\mathrm{w}$ Socrates undeniably fails to persuade his partner. Alcibiades, as described in Symposium, reverted to his initial beliefs and turned away from philosophy (216a). Even though he is still in 1 with Socrates (222c), he is unwilling to follow the way his lover illustrated in their first conversation, i.e., Alcibiades I. Apparently, Alcibiades does not want to subject himself to reason but to keep his own arbitrary mind. Instead of turning his eros toward truth and wisdom, he prefers to stay the way he is.

In face of Socrates' failure, the difficulty of his method becomes evident. Indeed, one might wonder if it is possible to apply it at all. Still, the interpretation of Alcibiades I offers some practica advice. Alcibiades I highlights the importance of eros for education. Only by appealing to the tudent's eros can one gain his or her attention. As long as the student is not addressed both on a intellectual and emotional - or better at an existential - level, it is unlikely that he or she is willing to listen. At this point, it is necessary for a reminder of what eros stands for. Eros is a strong desire for something we want but do not have yet. This means that if a teacher wants to inspire his or her student for the love of wisdom, the teacher needs to reveal that the student is not wise yet. Now, (n) something, we do not search for knowledge. And we only learn of our ignorance if our pretended knowledge is refuted. Once the student has accepted his ignorance and realizes that he needs to change, he is motivated to learn.

Appealing to the student's eros, however, is no guarantee for success. As we have seen in Alcibiades I, Socrates seduces Alcibiades but still cannot redirect the young man's eros. The reasons for Socrates' failure are difficult to detect and require a more detailed analysis. One starting point for further research may be to put oneself in Alcibiades' shoes in his dialog with Socrates. This approach may offer insight into Alcibiades' mind and the limits of philosophical seduction - and at best, it may lead to self-knowledge.

\section{Notes}

1 Thomas C. Brickhouse and Nicholas D. Smith, "Socratic Teaching and Socratic Method," in The Oxford Handbook of Philosophy of Education, Harvey Siegel, ed. (Oxford: Oxford University Press, 2009), 183 2 For chronology of the dialogs, refer to Leonard Brandwood, "Stylometry and Chronology," in The Cambridge Companion to Plato, Richard Kraut, ed. (Cambridge: Cambridge University Press, 1992), 90-120; Terence H. Irwin, "The Platonic Corpus," in The Oxjord Handbook of Plato, Gail Fine, ed. (Oxford: Oxford University Press, 2009), 63-87; Gerard R. Ledger, Re-counting Plato: A Computer Analysis of Plato's Style (Oxford: Clarendon Press; Oxford University Press, 1989).

3 Nicholas Denyer, Alcibiades (Cambridge: Cambridge University Press, 2001), 3f; Andre Archie, Politics in Socrates' Alcibiades: A Philosophical Account of Plato 's Dialogue Alcibiades Major (Cham Springer, 2015), 4.

Brickhouse and Smith, "Socratic Teaching and Socratic Method," 184

Plato, Apology, in Plato: In twelve volumes, R.G. Bury, ed. (Cambridge: Loeb Classical Library and Harvard University Press, 1984), 23a. All in-text citations and translations of Plato's dialogs are taken

6 Brickhouse and Smith, "Socratic Teaching and Socratic Method," 179.

8 See Jacqueline Romilly, Alcibiade ou les dangers de l'ambition (Paris: Éd. de Fallois, 1996), 28.

9 For the interwoven plots and background story, see Barbara Zehnpfennig "Einleitung" in Symposion: Griechisch-deutsch, Barbara Zehnpfennig, ed. (Hamburg: Meiner, 2000), VIII.

10 Capitalized Eros refers to the mythological god, while lower-cased eros denotes the psychological phenomenon of passion and love.

1 According to Zehnpfennig, the awareness of an intellectual principle behind the forms of appearance helps the lover to transcend himself: he can no longer arbitrarily define what beauty means for him personally but has to gain an objective access. This becomes even more evident when Diotima speaks about beautiful laws and virtues which, by definition, surpass the individual. Barbara Zehnpfennig, Platon zur Einfihirung (Hamburg: Junius, 2005), 152 .

12 Gregory Vlastos, Platonic Studies (Princeton, NJ: Princeton University Press, 1981), 31.

Descendant of some of the most prestigious Athenian royal houses, Alcibiades was raised by Pericles. He was said to be the most beautiful, most talented, and most infamous man of his time: he provoked numerous 
scandals, won the Olympic Games, led the Athenians to several military victories, was sentenced to deatl by his compatriots and later brought back from exile and celebrated like a star. Peter J. Rhodes, Alcibiade (Barnsley: Pen \& Sword Military, 2011); Walter M. Ellis, Alcibiades (London: Routledge, 2014).

14 Nussbaum emphasizes the personal character of the whole Symposium and the task of self-examinatio that Socrates indirectly demands by challenging the previous images of love. Nussbaum is right to tak Alcibiades into consideration even though she fails to link his speech to Diotima's theory and Socrates practice. Martha Nussbaum, "The Speech of Alcibiades: A Reading of Plato's Symposium," Philosoph. and Literature 3/2 (1979): $133 f$.

indel reject his model (Replic, 473e)

16 To solve this part pon the pivotal orientation toward the good.

ons which do not provide the philosopher-kings are defective. Thes constitions or the following order: timocracy, oligarchy, democracy, and tyrann

represented by a father who passes some characteristics to his son who represents the future constitution represented by a father who passes some characteristics tight raise a democratic son and so on.

19 They might correspond to those who try and distract a young talented man from philosophy to manipulat him, like Socrates described earlier (Republic, 494c/d).

20 Socrates cassifies two sorts of desires: necessary and unnecessary ones which in turn can be either legal o illegal (Republic, 571b).

21 For examples, see Dominic Scott, "Eros, Philosophy and Tyranny," in Maieusis: Essays in Ancier Philosophy in Honour of Myles Burnyeat, Myles Burnyeat and Dominic Scott, eds. (Oxford: Oxfor University Press, 2007), 154

22 Ibid., 138

23 Scott states that the philosopher is asocial, i.e., he disregards the political in favor of the divine. Ibid., 151 This seems plausible only in parts: It is true that the philosopher has no interest in common politice competition as exemplified in the ship metaphor (Republc, 4876-489a). But Soctest calls hilse "tru statesman" (Gorgias, 521d) who dedicates his life to Athens cause (Apology, 30e). The philosopher is n interested in political affairs in general, he just has ano A nat 24 One of the leading motives in the Reprich

25 Because of Schleiermacher's harsh comment on Alcibiades $I$ in the nineteenth century, the dialog authe "Alcibiades I?"'Apein on: A Journal for Ancient Philosophy and Science 37/2 (2004): 93-108; Jakub Jirsa, "Authenticity of th Alcibiades I. Some Reflections." Listy filologické/ Folia philologica 132/3-4 (2009): 225-44. At presen scholars tend to be accepting Plato's authorship, with which I agree. Eugenio Benitez. "Authenticit Experiment or Development: The Alcibiades I on Virtue and Courage," in Alcibiades and the Socrat Lover-Educator. Marguerite Johnson, ed. (London: Bristol Classical Press, 2012), 119-33; Franco Renaud "Self-Knowledge in the First Alcibiades and the conmentary of Olympiodorus," in Inner $L$ j and Soul: Psychē in Plato, Maurizio Migliori, ed. (Sankt Augustin: Academia, 2011), 207; Denye Alcibiades.

26 According to the idea of paiderastia, the relationship, which was clearly hierarchical, usually ended whe the young lover's beard started to grow. The twenty-year-old Alcibiades was too old for a convention love affair. Carola Reinsberg, Ehe, Hetärentum und Knabenliebe im antiken Griechenland (Münche Beck, 1993), 165 .

27 For a detailed comparison between Alcibiades and the tyrant described in Republic, see Annie Larivé "Eros Tyrannos: Alcibiades as the Model of the Tyrant in Book IX of the Republic," The Internation ion 6/1 (2012): 1-26.

28 The historical Alcibiades allegedly mocked his numerous lovers on various occasions. Rhode Alcibiades, 25f.

29 For some interpreters, this passage proves the dialog's inauthenticity, see Smith, "Did Plato Write th

30 Gordon and Kühn suggest this reading, too. Gordon adds that Socrates' way of claiming his power ov Alcibiades may also impress the young man. Jill Gordon, "Eros and Philosophical Seduction in Alcibiad I," Ancient Philosophy 23/1 (2003): 27; Ulrich Kühn, "Das Liebesverhältnis zwischen Alkibiades ur Sokrates: Der platonische Bericht," Perspektiven der Philosophie: Neues Jahrbuch 37 (2011): 96.

31 Rider adds that by this way Socrates forces Alcibiades to reflect on his ambitions and what he wants his life. Benjamin A. Rider, "Self-Care, Self-Knowledge, and Politics in the "Alcibiades I," Epoch A Journal for the History of Philosophy 15/2 (2011): 403.
32 See the twenty-fifth endnote

33 Catherine H. Zuckert, Plato's Philosophers: The Coherence of the Dialogues (Chicago: University of Chicago Press, 2009), 22

34 Brüschweiler notes that Socrates may veil the difference between his and Alcibiades' understanding of power on purpose to keep the young man's expectations high. Andreas Brïschweiler, Sokrates' Jugend

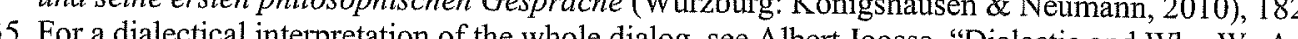

Alcibiades," Phronesis 59/1 of the whole dialog, see Albert Joosse, "Dialectic and Who We Are in the 6 Griblades, Phronesis 59/1 (2014): 1-21.

291; Friedrich Schleiermacher, Über die Philosohhie Plat. (Princeton: Princeton University Press, 1996) über Solrates und Platon (zwischen 1819 und 1823). Die Einleitungenichte der Philosophie. Vorlesunge 1828), P.M. Steiner, A. Arndt, J. Jantzen with assistance (Hamburg: Felix Meiner Verlag 2013),

37 Carpenter and Polansky offer a slightly different interpretation: they distinguish two types of refutation. First, Socrates argues that Alcibiades' prejudice on his enemies has bad consequences, namely deficient self-care. Second, Socrates shows in his long speech that Alcibiades' view is likely to be false. Still, both approaches seem to intertwine. Michelle Carpenter and Ronald M. Polansky, "Variety of Socratic Elenchi," in Does Socrates Have a Method? Rethinking the Elenchus in Plato's Dialogues and Beyond, Gary A Scott, ed. (University Park: Pennsylvania State University Press, 2002), 95; see Gordon, "Eros and Philosophical Seduction in Alcibiades," 15; Christopher L. Lauriello, "Political Science and the Irrational: Plato's Alcibiades," Interpretation. A Journal for Political Philosophy 37/3 (2010): 245.

38 Karl observes that the practical problem - how to become a good politician - turns into the existentia question of what it means to live a good life. Jacqueline Karl, Selbstbestiminung und Individualität be Platon: Eine Interpretation zu fruihen und mittleren Dialogen (Freiburg: K. Alber, 2010), 90

39 In the following, Socrates states that this is the most divine part of the soul. This means that by looking at God the soul knows itself. Because this passage is peculiar in many aspects, some scholars assume that it was

40 This counterpart does not necessarily have to be another person. In Theaetetus, Socrates explains that thinking is nothing more than dialoguing with oneself $(189 \mathrm{e})$.

41 According to Rider, Sore than dialoguing win oneself (189e). young man what he really wants in life; second by acceting his deficiency Alcige. Hirst, he shows the the standard he has to achieve, i.e he needs to look for the true self. Annas, Alcibiades is able to look fo she emphasizes that the self which Alcibiades is looking for is his personal self and wo im lower incorporation of the good or even God. In her view, self-knowledge means knowing one's socis polital. Rider replies that this reading fails to integrate the aspect of self-cultivation: improving one's soul only makes sense if it is not perfect yet. Moreover, Gordon criticizes Annas' interpretation of self-knowledge by pointing at the "inner dimensions of the self." For her, Socratic self-knowledge focuses on getting to know and cultivating one's eros. Rider, "Self-Care, Self-Knowledge, and Politics in the 'Alcibiades I,", 405-7; Julia Annas, "Self-knowledge in Early Plato," in Platonic investigations, Dominic J. O'Meara, ed (Washington, DC: Catholic University of America Press, 1985), 121; Gordon, "Eros and Philosophical Seduction in Alcibiades I," 21

42 The idea that self-knowledge is only accessible through dialog also explains why Socrates emphasizes several times the importance of joint consideration and the necessity of Alcibiades answering his questions. For this interpretation see Rider, "Self-Care, Self-Knowledge, and Politics in the "Alcibiades I,"
$402-5$; see Joosse, "Dialectic and Who We Are in the Alcibiades," 20.

\section{Bibliography}

Ambury, James M. 2011. "The Place of Displacement: The Elenchus in Plato's Alcibiades I." Ancient Philosophy 31/2: 241-60.

Annas, Julia. 1985. "Self-knowledge in Early Plato." In Platonic Investigations. Dominic J. O'Meara ed. Washington, DC: Catholic University of America Press: 111-38.

Archie, Andre. 2015. Politics in Socrates' Alcibiades: A Philosophical Account of Plato's Dialogue Alcibiades Major. Cham: Springer.

Benitez, Eugenio. 2012. "Authenticity, Experiment or Development: The Alcibiades I on Virtue and Courage." In Alcibiades and the Socratic Lover-Educator. Marguerite Johnson ed. London: Bristol Classical Press: 119-33.

Brandwood, Leonard. 1992. "Stylometry and Chronology." In The Cambridge Companion to Plato. Richard Kraut ed. Cambridge: Cambridge University Press: 90-120 
Brickhouse, Thomas C. and Nicholas D. Smith. 2009. "Socratic Teaching and Socratic Method." In The Oxfo Handbook of Philosophy of Education. Harvey Siegel ed. Oxford: Oxford University Press: 177-94. Brüschweiler, Andreas. 2010. Sokrates' Jugend und Seine Ersten Philosophischen Gespräche. Würzbur Königshausen \& Neumann.

Carpenter, Michelle and Ronald M. Polansky. 2002. "Variety of Socratic Elenchi." In Does Socrates Have Method? Rethinking the Elenchus in Plato's Dialogues and Beyond. Gary A. Scott ed. University Par Pennsylvania State University Press: 89-100.

Denyer, Nicholas. 2001. Alcibiades. Cambridge: Cambridge University Press.

Ellis, Walter M. 2014. Alcibiades. London: Routledge.

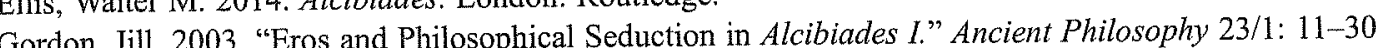
Gordon, Jil. 2003, "Eo9 "The Platonic Corpus" In The Oxford Handbook of Plato. Gail Fine ed. Oxfor Oxford University Press: 63-87.

Oxord Unive . "Al Some Reflections." Listy filologické/ Folia philologi 132/3-4: $225-44$

132/3-4: 225-44. "Dialectic and Who We Are in the Alcibiades." Phronesis 59/1: 1-21.

Karl, Jacqueline. 2010. Selbstbestimmung und Individualität bei Platon: Eine Interpretation zu frühen u mittleren Dialogen. Freiburg: K. Alber

Kühn, Ulrich. 2011. "Das Liebesverhältnis zwischen Alkibiades und Sokrates: Der platonische Berich Perspektiven der Philosophie: Neues Jahrbuch 37: 75-114.

arivée, Annie. 2012. "Eros Tyrannos: Alcibiades as the Model of the Tyrant in Book IX of the Republis The International Journal of the Platonic Tradition 6/1: 1-26.

Lauriello, Christopher L. 2010. "Poltical Science and the Irrational: Plato's Alcibiades." Interpretation. Journal for Political Philosophy 37/3: 237-57.

Ledger, Gerard R. 1989. Re-counting Plato: A Computer Analysis of Plato's Style. Oxford: Clarendon Pre Oxford University Press.

Nussbaum, Martha. 1979. “The Speech of Alcibiades: A Reading of Plato's Symposium." Philosophy a Literature 3/2: 131-72.

Reinsberg, Carola. 1993. Ehe, Hetärentumn und Knabenliebe im antiken Griechenland. München: Beck. Renaud Francois. 2011. "Self-Knowledge in the First Alcibiades and the Commentary of Olympiodoru In Inner Life and Soul: Psychè in Plato. Maurizio Migliori ed. Sankt Augustin: Academia: 207-24. in ies, Peter J. 2011. Alcibiades. Barnsley: Pen \& Sword Military.

Rider, Penjomin A 2011 "Self-Care, Self-Knowledge, and Politics in the "Alcibiades I." Epoche: Journal for the History of Philosophy 15/2: 395-413.

Journal for the History of Philosophy 15/2: 395-413.
Romilly, Jacqueline D. 1996. Alcibiade ou les dangers de l'ambition. Paris: Éd. de Fallois.

Romilly, Jacqueline D. 1996. Alcibiade ou les dangers de l ambillons Pichte der Philosophie Vorlesung Schleiermacher, Friedrich. 2013. Uber die Philosophie Plans. Geschiche der Philosophie. Vorlesung

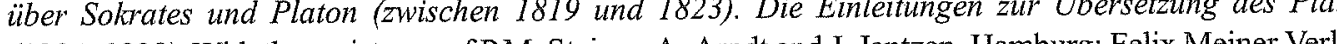
(1804-1828). With the assistance of P.M. Steiner, A. Ardt and. Jantzen. Hanburg: Felix Meiner Verl Scott, Dominic. 2007. "Eros, Philosophy and Tyranny." In Maieusis: Essays in Ancient Philosophy Honour of Myles Burnyeat. Myles Burnyeat and Dom $136-54$

Smith, Nicholas D. 2004. "Did Plato Write the "Alcibiades I?"' Apeiron: A Journal for Ancient Philosor and Science 37/2: 93-108.

Vlastos, Gregory. 1981. Platonic Studies. Princeton: Princeton University Press.

Vlastos, Gregory. 1996. The Presocratics. Daniel W. Graham ed. Princeton: Princeton University Press Zehnpfennig, Barbara ed. 2000. "Einleitung." In Symposion: Griechisch-deutsch. Hamburg: Meiner.

Zehnpfennig, Barbara, 2005. Platon zur Einführung. Hamburg: Junius.

Zuckert, Catherine H. 2009. Plato's Philosophers: The Coherence of the Dialogues. Chicago: University Chicago Press. 